\title{
Effect of Poultry Manure on Growth and Yield of Local Varieties of Okra (Abelmoschus esculentus)
}

\author{
Ibeh, C.U. Nsoanya L.N. Nweke I. A. \\ Department of Crop Science Chukwuemeka Odumegwu Ojukwu University, Igbariam Anambra State, Nigeria
}

\begin{abstract}
Field experiments were conducted during 2012 rainy seasons to study the effects of poultry manure on growth and yield of some selected local varieties of Okra (Abelmoschus esculentus). The experiment was laid out in a Randomized Completed Block Design (RCBD), replicated four times. The results show that three were significant differences in growth characteristics and yield of the varieties. There were significant yield depression tha ${ }^{-1}$ by $21.8 \%, 21.9 \%, 49.8 \%$ and $63.4 \%$, when Kwanab bokodo was compared with Kwanab magwandara, Kwanab kwete and Lady's finger (control), on fresh weight basis. However on dry weight basis, reverse was the case with lady's finger significantly out-weighing (Kwanab magwandara by $14.50 \%, 25.4 \%$, Kwanab bokodo by $34.7 \%$ and Kwanab kwete by $56.9 \%)$. There were also significant variations in the length of pods/plant $(\mathrm{cm})$, leave area per plant $\left(\mathrm{cm}^{2}\right)$, number of leaves per plant and number of branches per plant. This implies that lady's finger with higher pod dry matter yield there has higher productivity and contains more nutritional components than others.

Keywords: Poultry manure, Abelmoschus esculentus, Growth parameters and Yield parameters
\end{abstract}

DOI: $10.7176 / \mathrm{JBAH} / 9-3-08$

\section{INTRODUCTION}

Okra is a flowering plant belonging in the mallow family of Malvaceae, which originates from tropical and subtropical Africa and it is a native to West Africa (Tindall, 1983). Okra was formerly considered of specie of hibiscus, but is classified in the genus Abelmoschus. Abelmoschus esculentus (L) okra is now a widely cultivated vegetable and can be found in almost every market all over Africa (Schippers, 2000). The word okra is of African origin and means "Lady Fingers" in Igbo a language spoken in Nigeria. Okra is mainly cultivated for its pods which are cooked and eaten in countries like Sudan, Egypt, and Nigeria. It is also important in other tropical areas including Asia central and South America. In Nigeria, okra is grown both during the wet and dry season but attract larger profit during the dry season when the demand is often in excess of the limited supplies. Fresh okra fruits are used as vegetables while the roots and the stems are used for preparing "Gur" or the brown sugar (Chauhan, 1972). Most of the okra eaten is cooked or in processed form. Young okra fruits may be eaten raw. Okra seeds are used for oil extraction. The oil in the seeds could be as high as in poultry eggs and soya beans (Akinfasoye and Nwanguma, 2005). The nutritional constituents of okra includes calcium, protein, oil and carbohydrate, others are iron, magnesium and phosphorus. The leafy part of it plays a vital role in the improvement of the diet of mankind.

Okra production is very low in many developing countries. Most farmers rely mainly on innate fertility of the soil and in addition considerable amount of money so as to achieve a reasonable yield of okra. Fertilizer is a very essential input in okra production. Optimum crop production of okra requires intensive management practices that conserves and manage soil and nutrients needed for maintaining soil and water quality. Okra requires nutrient such as Nitrogen (N), Phosphorus (P), Potassium (K), Calcium (Ca), Sodium (Na) and Sulphur (S) for fertility maintenance and crop production. Research has shown that poultry manure (organic fertilizer) contains high percentage of the above named elements for the healthy growth of okra plants (Ewulo, 2005).

Corrales et al., (1990) noted that yield advantages accruing from the application of inorganic fertilizer but cautioned on the negative influence of their cost and availability resulting in the popularity of organic manure (poultry manure) as means of supplementing negative soil fertility in tropical areas. The poultry manure makeup nutrients are specific in function and must applied to the plant at the right time and at the right quantity. Lack of sufficient amounts of these nutrients results in poor performance of the crop with growth been affected resulting to low yield (Shukla and Naik, 1993).

The use of organic manure especially poultry droppings for crop production has helped to improve agricultural practices in West African countries. Organic manure helps to improve the physical condition of soil such as structure, water holding capacity, aeration and drainage and provides adequate amount of necessary nutrients for the soil productivity. Organic fertilizer (poultry manure) plays vital role as a major contributor of plant nutrients. It is also act as a store room or house for cation exchange capacity (CEC) and as a buffering agent against undesirable $\mathrm{pH}$ fluctuation (Adepetu and Corbley, 1987). Okra responds well to the dressing of organic manure (Palm et al., 1997) gave the importance of organic fertilizer as essential tools in okra production. Okra can also be given combination of organic fertilizers to improve the fruit yield and to supply balance nutrient to the crop (Mario et al., 1989). This research was aimed to access the effect of poultry manure on growth and yield of local varieties of okra (Abelmoschus esculentus). Below are the specific objectives of the study,

i. To determine the effect of poultry manure on growth of some selected local varieties of okra 
ii. To determine the effect of poultry manure on yield of some selected local varieties of okra

iii. Comparing the growth and yield effect of poultry manure on the selected okra varieties.

\section{Materials and Methods}

Site Description: The experiment was carried out on June, 2012 at the students teaching and research farm of the faculty of Agriculture, Anambra State University now Chukwuemeka Odumegwu Ojukwu University Anambra state, Igbariam Campus. Anambra State is located at latitude $5^{\circ} 40$ and $6^{\circ} 46 \mathrm{~N}$, longitude $6^{\circ} 40$ and $7^{\circ} 20 \mathrm{E}$. The annual rainfall of the area varies from $1800 \mathrm{~mm}$ to about $2500 \mathrm{~mm}$, the temperature of the area vary from $21^{\circ}$ to over $25^{\circ}$ while relative humidity is from $60 \%$ to over $85 \%$.

Soil Analysis: Soil analysis of the experimental site prior to planting was based on the composite samples taken randomly at the four different blocks of the experimental unit with the use of $15 \mathrm{~cm}$ auger deep. The composite samples were air dried under the sun at the Soil Science laboratory of the University for 3 days and later crushed and sieved using a $2 \mathrm{~mm}$ sieving mesh. The primary particles were discarded and the fine earth fractions were taken for physical and chemical analysis in the laboratory. The soil in the experimental area was classified as silt loam which was as a result of USDA soil classification in the year 1975.

Field Preparation: the experimental area measuring $16 \mathrm{~m} \mathrm{x} 12 \mathrm{~m}\left(192 \mathrm{~m}^{2}\right)$ was cleared and divided into 16 different blocks using pegs and line. The division gave measurement of $3.25 \mathrm{~m} \mathrm{x} 12 \mathrm{~m}\left(39 \mathrm{~m}^{2}\right)$ with $1 \mathrm{~m}$ path ways between the blocks. Later, the blocks were divided into 16 plots which gave $2.55 \mathrm{~m} \times 3.25 \mathrm{~m}\left(8.29 \mathrm{~m}^{2}\right)$ per plot with $0.6 \mathrm{~m}$ path ways between the plots.

Experimental Design, Treatment and Treatments Allocation: the seeds were sowed in the farm following randomization sequence of the plots for the four different okra varieties which includes;

i. $\quad$ T1 (Control) - Ladys finger

ii. $\quad$ T2 - Kwanab magwandra

iii. T3 - Kwanab bokodo

iv. T4 - Kwanab kwete

Obtaining and sowing of seeds: the four okra varieties were procured from the irrigation engineer in the faculty. The okra seed were soaked in clean water for 5 hours to test the viability of the seeds after which the floating seeds were discarded and the remaining were taken to the farm. The seeds were sowed on $23^{\text {rd }}$ June, 2012 at a spacing of $60 \mathrm{~cm} \times 60 \mathrm{~cm}$ with $3-4$ seeds per hole at $1 / 2$ inch depth having a plot population of 20 plants per plot after thinning to 1 plant per stand to reduce competition. This plants population per plot after summing gave 80 plants per block and 320 plants stands in the experimental area.

Fertilizer Application: organic manure (poultry droppings) was applied 2 weeks after planting in the rate of $6 \mathrm{~kg}$ per plot.

Weeding, pest, diseases and their control: weed control was carried out manually using hoe at 2 weeks interval, while pest control was carried out using insecticide, Nuvacron $40 \mathrm{SCW}$ water soluble concentrate at the rate of $60 \mathrm{~g}$ a.i and at 9 liter per hectare. No disease incidence was noticed on the crops.

Data Collection: data were collected on height of shoot, girth of stem, leaf area, number of leaves, number of branches, pod fresh weigh, pod dry weight, length of pod, pod diameter and number of flower at 12 weeks after planting.

Data Analysis: data were analyzed using Analysis of Variance (ANOVA) while treatment means were separated using the Least Significant Difference (LSD)

\section{Results}

The soil of the experimental site was classified as sandy loam based on the USDA (1975) classification guideline (Table 1). $\mathrm{pH}$ in water value of 6.5 much showed that the soil is slightly acidic in nature. The soil was low in organic carbon, total nitrogen and available phosphorus and moderate in organic compound. Exchangeable potassium $\left(\mathrm{K}^{+}\right)$and sodium $(\mathrm{Na})$ was low varying from $0.15 \mathrm{~mol} / \mathrm{kg}$ of soil. The proportion of silt is high and of considerable importance since it influences infiltration rate of water in the soil. 
Table 1: Physical and Chemical Characteristics of the soil used in the experimental site.

\begin{tabular}{lll}
\hline \hline Physical Characteristics & Units & Value \\
\hline \hline Depth & $\mathrm{Cm}$ & $0-15$ \\
Sand & $\%$ & 20.0 \\
Silt & $\%$ & 70.0 \\
Clay & $\%$ & 10.0 \\
Base saturation & $\%$ & 76.30 \\
\hline \hline & & Value \\
\hline Chemical Characteristics & & 6.50 \\
pH (H2O) & & 6.10 \\
pH (KCL) & $\%$ & 2.92 \\
Organic compound & $\mathrm{mol} / \mathrm{kg}$ & 1.30 \\
Total Nitrogen & $\mathrm{mol} / \mathrm{kg}$ & 6.33 \\
Available P & $\mathrm{mol} / \mathrm{kg}$ & 0.15 \\
Exchangeable Na & $\mathrm{mol} / \mathrm{kg}$ & 0.41 \\
Exchangeable Ca & $\mathrm{mol} / \mathrm{kg}$ & 0.25 \\
Exchangeable K & $\mathrm{mol} / \mathrm{kg}$ & 2.5 \\
Cation Exchange Capacity & &
\end{tabular}

Table 2: Summary of the weather records from June - September

\begin{tabular}{llccc}
\hline \hline Climatologically & June & July & August & September \\
\hline \hline Rainfall (mm) & 17.2 & 12.1 & 18.3 & 21.4 \\
Rain days (day) & 11 & 16 & 15 & 16 \\
Mean Min. Monthly Temp. & 17.9 & 16.1 & 23.4 & 22.6 \\
Mean Max. Monthly Temp. & 23.9 & 21.8 & 29.7 & 29.4 \\
Relative humidity (\%) at 6.00hrs & 54 & 50 & 74 & 73 \\
Relative humidity (\%) at 18.00hrs & 65 & 62 & 94 & 84 \\
\hline \hline
\end{tabular}

Source: Anambra State Ministry of Science and Technology Meteorological station at Anambra State University, Igbariam Campus.

Table 3: Average Plant height (cm), stem diameter (cm), No. of leaf per plant, Leaf area $\left(\mathrm{cm}^{2}\right)$ and $N o$. of branches per plant determined at 12 Weeks after Planting (WAP)

\begin{tabular}{|c|c|c|c|c|c|}
\hline Varieties & $\begin{array}{ll}\text { Plant Height } \\
(\mathrm{cm})\end{array}$ & $\begin{array}{ll}\begin{array}{l}\text { Stem } \\
(\mathrm{cm})\end{array} & \text { Girth } \\
\end{array}$ & $\begin{array}{ll}\begin{array}{l}\text { Leaf } \\
\left(\mathrm{cm}^{2}\right)\end{array} & \text { Area } \\
\end{array}$ & $\begin{array}{l}\text { Number of } \\
\text { Leaves }\end{array}$ & $\begin{array}{l}\text { Number } \\
\text { Branches } \\
\end{array}$ \\
\hline Lady finger & 78.63 & 4.52 & 366.13 & 9.08 & 1.92 \\
\hline $\begin{array}{l}\text { Kwanab } \\
\text { magwandra }\end{array}$ & 57.39 & 4.71 & 420.79 & 13.04 & 3.78 \\
\hline Kwanab bokodo & 83.31 & 4.33 & 548.96 & 11.98 & 1.69 \\
\hline Kwanab kwete & 82.75 & 6.23 & 1044.13 & 17.24 & 7.16 \\
\hline F-LSD 0.05 & 4.35 & 0.84 & 109.17 & 2.20 & 0.71 \\
\hline
\end{tabular}

The sampled plant heights differs significantly and also statistically only that Kwanab bokodo and Kwanab kwete have similar plant height with $83.31 \mathrm{~cm}$ and $82.75 \mathrm{~cm}$ respectively with Kwanab magwandra having the least plant height of $57.63 \mathrm{~cm}$. the plant stem girth does not differ significantly but statistically, Kwanab kwete have the highest stem girth of $6.23 \mathrm{~cm}$, also Kwanab kwete have the highest leaf area of $1044.13 \mathrm{~cm}^{2}$ followed by Kwanab bokodo $\left(548.96 \mathrm{~cm}^{2}\right)$, then Kwanab magwandra $\left(420.79 \mathrm{~cm}^{2}\right)$ and Lady finger $\left(366.13 \mathrm{~cm}^{2}\right)$. Similarly, the number of leaves of the plants does not differs significantly but differs statistically, the number of branches of the plants differs significantly and also statistically. 
Table 4: Average Number of flowers per plant, Length of pod (cm), Pod diameter (cm), Pod fresh weight (tha-1) and pod dry weight (tha-1).

\begin{tabular}{|c|c|c|c|c|c|}
\hline Varieties & $\begin{array}{l}\text { Number of } \\
\text { flowers }\end{array}$ & $\begin{array}{l}\text { Length of pods } \\
(\mathrm{cm})\end{array}$ & $\begin{array}{l}\text { Pod diameter } \\
(\mathrm{cm})\end{array}$ & $\begin{array}{l}\text { Pod fresh weight } \\
\left(\text { tha }^{-1}\right)\end{array}$ & $\begin{array}{l}\text { Pod dry weight } \\
\left(\text { tha }^{-1}\right)\end{array}$ \\
\hline Lady finger & 2.25 & 9.87 & 8.17 & 197.20 & 10.09 \\
\hline $\begin{array}{l}\text { Kwanab } \\
\text { magwandra }\end{array}$ & 3.75 & 8.15 & 10.78 & 158.01 & 8.81 \\
\hline Kwanab bokodo & 3.62 & 5.17 & 9.37 & 192.66 & 7.49 \\
\hline Kwanab kwete & 2.08 & 8.45 & 8.26 & 128.54 & 6.43 \\
\hline F-LSD 0.05 & 0.43 & 1.36 & 10.23 & 28.68 & 1.40 \\
\hline
\end{tabular}

In the yield of the varieties, the dry pod weight of the varieties does not differ significantly but differ statistically with Lady's finger having the highest dry pod weight of 10.09 tha $^{-1}$ followed by Kwanab magwandra then Kwanab bokodo and last Kwanab kwete, but the fresh pod weight of the varieties differs significantly and also statistically.

\section{Discussion}

Growth parameter: Result in Table 3 show that the differences in plant height and leaf area among the varieties were not significantly but the numbers of branches per plant, stem girth in Kwanab kwete were significantly higher $(p \geq 0.05)$ than the other varieties. This variety had very high mean plant height $(82.75 \mathrm{~cm})$, stem diameter $(6.23 \mathrm{~cm})$, leaf area per plant $(1044.13 \mathrm{~cm} 2)$ at 12 WAP furthermore, the number of branches of Kwanab kwete (7.16) was statistically higher than the mean value for other varieties used in the experiment.

Dry pod yield and number of flowers per plant did not differ significantly vary among the varieties, but fresh pod yield, pod length and pod diameter were significantly different $(p \geq 0.05)$. the non significance of the pod yield on dry weight basis as against the statistical significance of this variables on fresh weight basis is indicative of the differences in moisture content of the fruit yields, which was lowest in Lady's finger (91.4\%) and highest in Kwanab bokodo (96.1\%) and about $94 \%$ in other varieties. This result has implications for the culinary qualities of the varieties. In respect of plant heights, leaf area and number of branches per plant, the results are in agreement with Sabatu (2002), who made the same observation when working with similar varieties in Zuru. According to Harper (1983), for a meaningful consideration to be made, these parameters should be correlated with dry matter production in order to determine growth and yield and this is the case in this research.

Yield parameter: Results in Table 4 indicate that there were statistically significant differences among the varieties when the yield and yield components were compared. From the results obtained, it could be observed that the shorter the plant, the higher the yield. Kwanab kwete having larger leaf area $\left(1044.13 \mathrm{~cm}^{2}\right)$ and also more leaves per plant had significantly lower yield (tons $\mathrm{ha}^{-1}$ ) when compared with the control (lady's finger). The trend followed by this result was not expected since the area of leaf surface is used as an index to quantify the photosynthetic accumulations of any plant. The anomaly observed from the result of this experiment in this regard may be due to greater number of pods formed after flowering, which may have helped to, improved the plant photosynthesis. Another reason may be that the yield potential of this variety may be genetically fixed since genetic makeup of an individual affects its performance generally. Also, environmental factors may have influenced their yield since they were grown under the same environmental conditions. The assumption that all the leaves contribute to the growth and yield has been challenged (Harper, 1983) since the older the leaves, the less efficient they are in light conversion and so low photosynthetic performance. Bleasdale (1973) described a range of techniques for measuring leaf areas and indicated that calculations based on dry weight basis improved the efficiency. However, it had been noted that electrophiles are generally more efficient than planophiles in contributing to photosynthesis efficiency. Harper (1983) stressed that leaf arrangement; position and angle of presentation to incoming radiation are other factors that can make adequate contributions to photosynthetic efficiency that subsequently affect growth and yield in crop production.

\section{Conclusion}

Yield potentials of the test crops are determined by the genetic makeup of the individual crop plant. Environmental factors may have helped to realize the yield potentials of the lady's finger. However, with higher pod dry matter yield (PDMY), the lady's finger contains more nutritional component than the others.

\section{Recommendation}

It is recommended that organic manure (poultry manure) should be used in vegetable (okra) production due to its constituent to enrich both the soil and plant itself.

\section{References}

Adepetu, J.A and S.A. Cobley., (1987). Organic phosphorus predictor of plant available Phosphorus in soils of 
southern Nigeria. Soil Science, 122(3): $22-38$.

Akinfasoye, J.A. and Nwaguma, E.I., (2005). Vegetable growths of Telfaria occidentalis Hook, F and staking pattern in Telfaria/okra intercrop in a valley bottom dry season cultivation. Proceedings of the Horticultural Society of Nigeria Annual Conference, Sept. 18 -22, Port Harcourt, pp: 67 -71.

Bleasdale, J.K.A., (1973). Plant physiology in relation to horticulture. Macmillan publication, London and Basingstoke, pp: $21-71$.

Corrale, G., Guerra, A., and Montes de Oca, F., (1990). Potassium fertilization effect on yield and its components in banana vicands in a brown with carbonates soil ciencia. Technical Enla. Agric., 13: 7 - 16.

Ewulo, B.S., (2005). Effect of poultry and cattle manure on sandy clay loam soil. J. Anim. Vet. Sci., 4: 839841.

Harper, F., (1983). Principles of arable crop production. Blackwell Science Ltd., London, pp: 336.

Palm, C.A., Myers, J.K., and Nandwa, S.M., (1997). Combined use of organic and inorganic nutrient sources for Soil fertility maintenance and replenishment. Soil Science Society of America Special Publication 51: 193 217.

Sabatu, U.E., (2002). Studies on the growth characteristics and yield of some selected varieties of Okra HND project College of Agriculture, Zuru, pp: 60.

Schippers, R.R., (2000). African indigenious vegetables an overview of cultivated species. Natural resources institute, Chatham, Uk, pp: 89.

Shukla, V., and Naik, L.B., (1993). Agro-Technique for Malvaceae vegetables, In: Ifovance in horticulture vol5. Malhotra publishing house, New Delhi, India, pp: 399 - 425.

Tindall. H.D., and Rice, R.P., (1983). Fruit and vegetable production in warm climates. The Macmillan press Ltd. Nig. Pp: 85 . 